\title{
Evaluasi Karakteristik Mikro-Fisik dan Mekanik Pasir Vulkanik Tersementasi di Tebing Sungai Aliran Lahar Gunung Kelud
}

\author{
Astari $^{1 *}$, Andre Primantyo Hendrawan ${ }^{1}$, Emma Yuliani $^{1}$ \\ ${ }^{1}$ Jurusan Teknik Pengairan, Fakultas Teknik, Universitas Brawijaya \\ Jl. MT. Haryono No. 167, Malang, 65145, Indonesia \\ *Korespondensi Email: ayiastari061@gmail.com
}

\begin{abstract}
The volcanic sand slopes with pyroclastic materials resulted from Mount Kelud eruption has a unique characteristic in its microstructure-the porous fabric where its particles and bindings are interlocked or cemented each other. This research identifies micro-physical characteristics, cemented volcanic sand mineralogy, and effect on the shear strength of the slopes. Analysis of the physical properties of the sieve test has good and bad gradations and the specific gravity value of the soil of $2,783-2,803$. The void ratio dan relative density with $\operatorname{Dr} 50 \%$ is $0,713-0,775$ and Dr 70\% is $0,639-0,720$. Absorption capacity test shows 6,383\%-7,759\%. Scanning Electron Microscopes identified scattered air cavities on the surface grains filled with very fine volcanic ash particles with sphericity and roundness including high sphericity and categories of angular to sub-angular grains in oblate shape. Analysis of the mineralogical characteristics of the X-RD, SEM-EDX, and X-RF produce total content of $\mathrm{SiO}_{2}+\mathrm{Al}_{2} \mathrm{O}_{3}+\mathrm{Fe}_{2} \mathrm{O}_{3}$, namely $80,3 \%-82,8 \%$ pozzolanic or cemented. Analysis of the mechanical characteristics of the direct shear test value is $39,74-$ $46,97^{\circ}(\operatorname{Dr} 50 \%)$ and $42,84-47,81(\operatorname{Dr} 70 \%)$, while the angle of repose value is 31,68 $-34,01^{\circ}$.
\end{abstract}

Keywords: Cemented, Shear Strength, Volcanic Sand Slopes.

Abstrak: Tebing pasir vulkanik dengan material piroklastik hasil erupsi Gunung Kelud memiliki sifat unik yang terdapat pada struktur mikronya, yaitu fabrik yang porous dimana partikel dan pengikatnya akan saling mengunci atau tersementasi. Penelitian ini mengidentifikasi karakteristik mikro-fisik dan mineralogi pasir vulkanik tersementasi serta pengaruh terhadap kuat geser tebing. Analisa karakteristik fisik uji distribusi butiran bergradasi baik dan buruk dan nilai berat jenis tanah 2,783 $-2,803$. Pengujian angka pori tanah dengan kerapatan Dr 50\% didapat 0,713-0,775 dan Dr 70\% didapat 0,639-0,720. Uji kapasitas absorpsi 6,383\% - 7,759\%. Scanning Electron Miroscopes mengidentifikasi adanya rongga udara yang tersebar di permukaan butiran yang dipenuhi partikel volcanic ash yang berukuran sangat halus dengan sphericity and roundness termasuk kedalam high sphericity dan kategori butiran angular hingga sub-angular berbentuk oblate. Analisa karakteristik mineralogi pengujian X-RD, SEM-EDX, dan X-RF menghasilkan kandungan total $\mathrm{SiO} 2+\mathrm{Al} 2 \mathrm{O} 3+\mathrm{Fe} 2 \mathrm{O} 3$ yaitu $80,3 \%-82,8 \%$ bersifat pozolanik atau tersementasi. Analisa karakteristik mekanik pengujian geser langsung diperoleh harga sudut geser dalam $39,74^{\circ}-46,97^{\circ}$ (Dr 50\%) dan $42,84^{\circ}-47,81^{\circ}$ (Dr 70\%), sedangkan nilai sudut tenang sebesar $31,68^{\circ}-34,01^{\circ}$.

Kata kunci: Kuat Geser, Tebing Pasir Vulkanik, Tersementasi. 


\section{Pendahuluan}

Gunung Kelud merupakan gunung berapi yang terletak di Provinsi Jawa Timur, perbatasan antara Kabupaten Kediri, Kabupaten Blitar dan Kabupaten Malang. Gunung Kelud terdapat sedikitnya 7 (tujuh) buah kubah lava di area sekitaran pusat erupsi ataupun yang terdapat pada erupsi samping [1]. Gunung ini termasuk dalam tipe gunung api stratovulkan dengan karakteristik letusan eksplosif. Gunung Kelud bererupsi secara eksplosif mengeluarkan material piroklastik yang terdiri dari dominan barupa abu, pasir vulkanik dan batuan beku seperti batu apung (pumice). Dari muntahan material piroklastik Gunung Kelud mengakibatkan deposit berupa batu dan pasir vulkanik yang hingga saat ini ditambangi oleh masyarakat sekitar dan berpotensi menyebabkan kelongsoran pada tebing sungai.

Tebing curam dengan material vulkanik yang berasal dari erupsi Gunung Kelud ini memiliki sifat unik yang didapat dari sktruktur mikronya, yaitu memiliki fabrik yang porous (berongga) partikel dan pengikat partikelnya akan saling mengunci (interlocked) atau tersementasi (cemented) oleh senyawa pengikatnya seperti mineral, unsur dan senyawa lainnya [2]. Tebing pasir tegak terindektifikasi bahwa tersusun dari deposit pasir yang tersementasi (cemented sand deposit) [3], [4]. Unsur pengikat yang paling umum berupa amorphous silica atau sileceous cement, kalsium karbonat atau calcareous cement, lempung atau argillaceous cement dan mineral yang mengandung besi [5].

Untuk meneliti kandungan unsur, senyawa dan mineralogi pasir vulkanik dan material piroklastik di Indonesia maka analisis dengan metode XRD (X-Ray Diffraction) [6]. Untuk mendapatkan evaluasi yang akurat tentang sifat mikro-fisik dan bentuk butiran pasir vulkanik Gunung Kelud maka analisis dengan SEM (Scanning Electrone Microscopy) [7]. Berdasarkan sifat mikro-fisik butiran, dua parameter geometrik telah umum dipakai untuk menganalisis bentuk butiran tanah dan sedimen, yaitu roundness dan sphericity. Roundness didefinisikan sebagai ukuran yang menggambarkan ketajaman (sharpness) dari ujung atau tepi butiran, sedangkan sphericity merupakan ukuran seberapa dekat suatu butiran mendekati bentuk bola (sphere). Berdasarkan beberapa referensi ini, penelitian tentang pengaruh karakteristik mikro-fisik terhadap sifat mekanik (kuat geser) pasir vulkanik tersementasi di lokasi penambangan pasir di Kali Putih Kabupaten Blitar sangat perlu untuk dilakukan.

\section{Bahan dan Metode}

\subsection{Bahan}

\section{A. Lokasi Studi}

Pengambilan sampel material ini di area Gunung Kelud yang secara geografis terletak pada $7^{\circ} 56^{\prime} 00^{\prime \prime}$ LS dan $112^{\circ} 18^{\prime} 30^{\prime \prime}$ BT dan berlokasi di tebing sungai penambangan pasir Gunung Kelud di daerah aliran lahar dingin Sungai Kali Putih Desa Karangrejo Kecamatan Garum Kabupaten Blitar. Terdapat 3 lokasi (3 titik) pengambilan sampel, yaitu lokasi A, B dan C yang berada pada tebing Sungai Kali Putih.

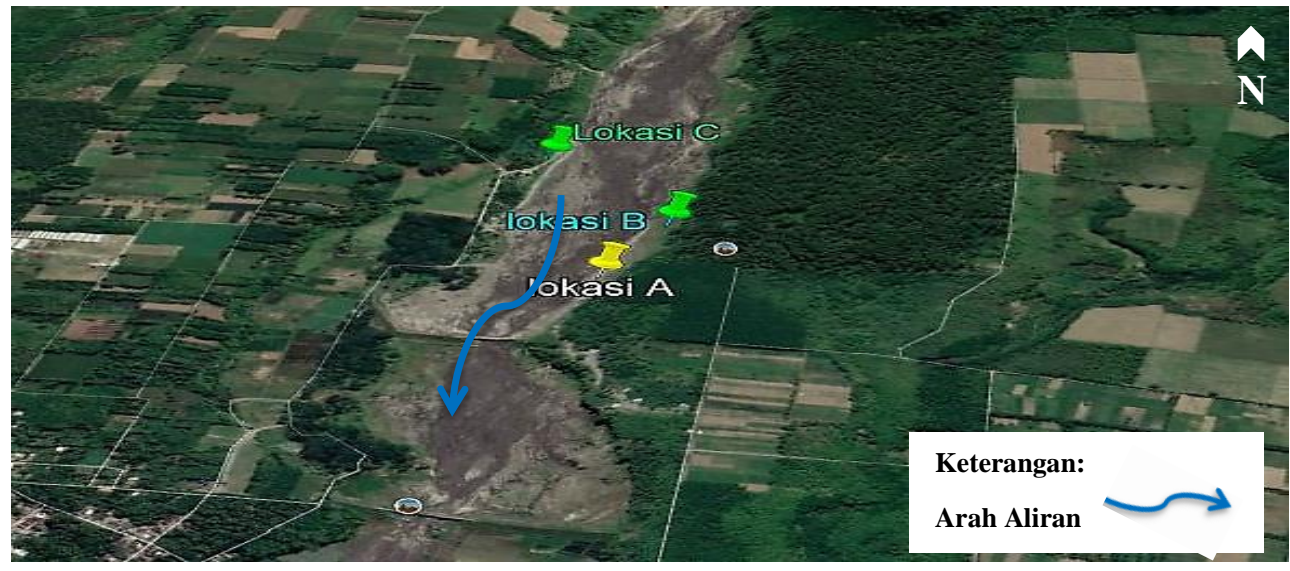

Gambar 1: Lokasi Pengambilan Sampel di Penambangan Pasir Sungai Kali Putih 


\subsection{Metode}

Setelah dilakukan pengambilan sampel di lokasi studi, selanjutkan dilakukan pengujian di laboratorium. Untuk pengujian klasifikasi tanah dan karakteristik fisik dilakukan di Laboratorium Tanah dan Air Tanah Jurusan Teknik Pengairan Universitas Brawijaya. Terdiri dari uji distribusi butiran tanah (sieve test) yang bertujuan untuk mengetahui gradasi dan ukuran butiran sampel. Uji berat jenis tanah (specific gravity) yang dilakukan untuk mengetahui perbandingan volume berat air. Uji angka pori (void ratio) dengan pemodelan kerapatan relatif (relative density) Dr 50\% dan Dr 70\% dilakukan untuk mengetahui pemadatan tanah di lapangan. Uji kapasitas absorpsi dilakukan untuk mengukur kemampuan butiran dalam menyerap air pada saat kondisi kering hingga kondisi jenuh permukaan kering atau SSD (Saturated Surface Dry). Uji sphericity and roundness dilakukan untuk mengetahui bentuk dari butiran. Uji Scanning Electron Microscopes (SEM) yang dilakukan di Laboratorium Sentral Mineral dan Material Maju Fakultas MIPA Universitas Negeri Malang bertujuan untuk mengetahui permukaan sampel pada perbesaran tertentu.

Untuk pengujian karakteristik mineralogi yang terdiri dari uji X-RD (X-Ray Difraction), uji SEMEDX (Scanning Electron Microscopes - Energy Dispersive) dan uji X-RF (X-Ray Fluorescence) dilakukan di Laboratorium Sentral Mineral dan Material Maju Fakultas MIPA Universitas Negeri Malang bertujuan untuk mengetahui kandungan mineral yang terkandung pada sampel serta mengetahui apakah pasir vulkanik memiliki sifat pozolanik atau mudah tersementasi. Dan pengujian karakteristik mekanik yaitu uji kekuatan geser langsung dengan pemodelan kerapatan Dr 50\% dan Dr 70\% dilakukan di Laboratorium Mekanika Tanah Jurusan Teknik Sipil Universitas Brawijaya dilakukan untuk mengetahui sudut geser dan nilai kohesi tanah. Sedangkan untuk pengujian sudut tenang dilakukan di Laboratorium Tanah dan Air Tanah Jurusan Teknik Pengairan Universitas Brawijaya yang bertujuan untuk mengethui sudut dalam hubungannya dengan kelongsoan pada setiap material sampel.

\section{Hasil dan Pembahasan}

3.1 Pengujian Distribusi Butiran Tanah (Sieve Test)

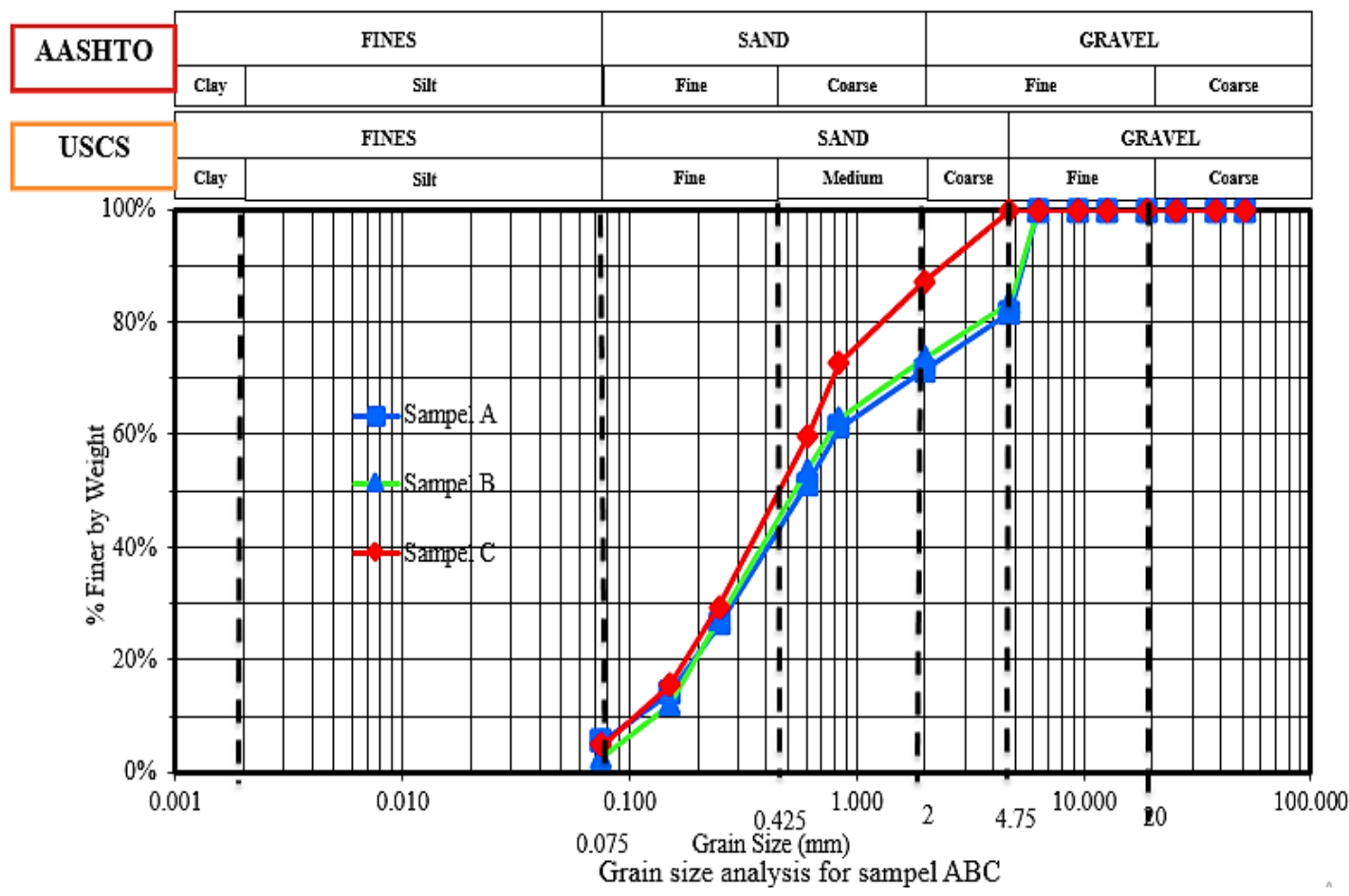

Gambar 2: Kurva Hasil Pengujian Distribusi Butiran Tanah pada Sampel A, B, dan C 
Untuk hasil pengujian distribusi butiran tanah di lokasi kelongsoran tebing sungai area penambangan pasir Sungai Kali Putih dapat dilihat pada Tabel 1:

Tabel 1: Klasifikasi Gradasi Butiran di Lokasi Pengambilan Sampel

\begin{tabular}{ccccccc}
\hline \multirow{2}{*}{ Sampel } & $\mathrm{D}_{10}$ & $\mathrm{D}_{30}$ & $\mathrm{D}_{60}$ & $\mathrm{Cu}$ & $\mathrm{Cc}$ & Klasifikasi Gradasi \\
& & & & & & \\
\hline A & 0,11 & 0,29 & 0,80 & 7,273 & 0,956 & Baik \\
B & 0,14 & 0,28 & 0,76 & 5,429 & 0,737 & Buruk \\
C & 0,10 & 0,27 & 0,60 & 6,000 & 1,215 & Baik \\
\hline
\end{tabular}

\subsection{Pengujian Berat Jenis Tanah (Specific Gravity)}

Untuk hasil pengujian berat jenis tanah (specific graity) dapat dilihat pada Tabel 2:

Tabel 2: Hasil Uji Berat Jenis Tanah pada Lokasi Studi

\begin{tabular}{ccc}
\hline Sampel & $\begin{array}{c}\text { Nilai Gs } \\
\text { gram } / \mathrm{cm}^{3}\end{array}$ & Jenis Tanah \\
\hline Sampel Tanah A & 2,783 & Pasir \\
Sampel Tanah B & 2,803 & Pasir \\
Sampel Tanah C & 2,691 & Pasir \\
\hline
\end{tabular}

Berdasarkan hasil diatas didapatkan nilai Gs dengan rentang 2,691 - 2,803 gram/ $\mathrm{cm}^{3}$ dan diklasifikasikan sebagai pasir. Nilai Gs yang didapat cukup tinggi dikarenakan adanya rongga-rongga yang tersebar di permukaan butiran sampel yang dipenuhi oleh partikel volcanic ash yang berukuran sangat halus. Adapun nilai berat jenis (Gs) untuk pasir vulkanik yang didapat dibandingkan dengan hasil penelitian oleh Devi Oktaviani Latif, Ahmad Rifa'i dan Kabul Basah Suryolelono (2016) dari Universitas Gadjah Mada dengan nilai Gs pada Gunung Kelud sebesar 2,50 gram/ $/ \mathrm{cm}^{3}$, Gunung Sinabung sebesar 2,57 gram $/ \mathrm{cm}^{3}$, dan Gunung Merapi sebesar 2,64 gram $/ \mathrm{cm}^{3}$ [8].

\subsection{Pengujian Kerapatan dan Angka Pori (Density and Void Ratio)}

Pada pengujian kerapatan dan angka pori untuk sampel pasir vulkanik di lokasi studi dilakukan dengan pemodelan kerapatan Dr 50\% (loose) dan Dr $70 \%$ (dense) yang bertujuan untuk mewakili kepatan tanah di lapangan. Dapat dilihat hasil pengujian pada Tabel 3:

Tabel 3: Hasil Perhitungan Kerapatan dan Angka Pori pada Sampel di Lokasi Studi

\begin{tabular}{cccccccccc}
\hline \multirow{2}{*}{$\begin{array}{c}\text { Samp } \\
\text { el }\end{array}$} & $\begin{array}{c}\text { Ws } \\
\text { Loose }\end{array}$ & $\begin{array}{c}\text { Ws } \\
\text { Dense }\end{array}$ & $\begin{array}{c}\gamma \mathrm{d} \\
\min \end{array}$ & $\begin{array}{c}\gamma \mathrm{d} \\
\max \end{array}$ & Gs & e max & e min & $\begin{array}{c}\text { e (Dr }= \\
50 \%)\end{array}$ & $\begin{array}{c}\text { e (Dr } \\
= \\
70 \%)\end{array}$ \\
\cline { 3 - 10 } & gram & gram & & & & & & & \\
\hline A & 538 & 628 & 1,456 & 1,699 & 2,783 & 0,912 & 0,638 & 0,775 & 0,720 \\
B & 546 & 678 & 1,477 & 1,834 & 2,803 & 0,897 & 0,528 & 0,713 & 0,639 \\
\hline
\end{tabular}

Untuk sampel tanah vulkanik A didapat nilai e pada Dr 50\% sebesar 0,775 dan nilai e pada $\operatorname{Dr} 70 \%$ sebesar 0,720. Adapun untuk sampel tanah vulkanik B didapat nilai e pada Dr 50\% sebesar 0,713 dan nilai e pada Dr 70\% didapat sebesar 0,639. Dapat disimpulkan bahwa tanah vulkanik A memiliki nilai angka pori yang lebih besar dari tanah vulkanik B untuk kerapatan tanah berbutir 50\% dan $70 \%$. Selain 
itu, hasil dari pengujian beberapa sampel pasir vulkanik di lokasi studi dibandingkan dengan korelasi dari Cubrinovski dan Ishihara (2002) dapat dilihat pada Gambar 4:

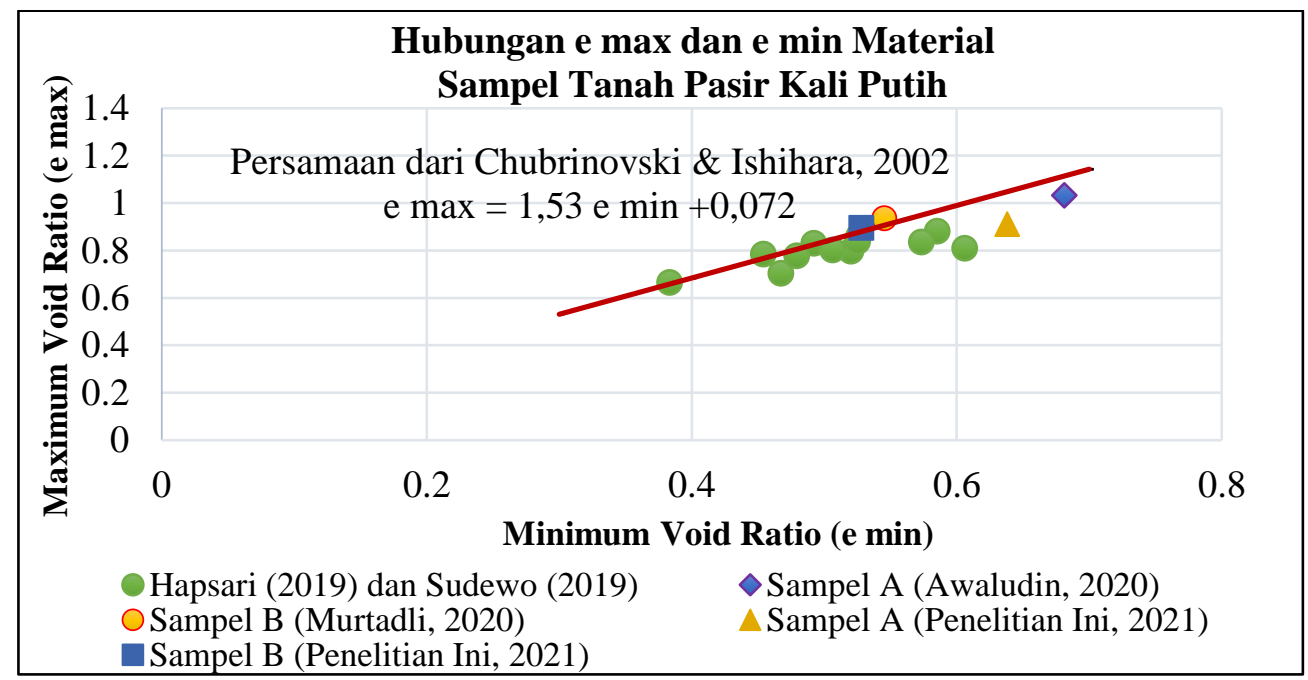

\section{Gambar 3: Grafik Hubungan e $e_{\max }$ dan $e_{\min }$ Pasir Vulkanik Gunung Kelud yang Dibandingkan dengan Korelasi dari Cubrinovski dan Ishihara (2002)}

Pada gambar di atas terlihat bahwa hubungan $\mathrm{e}_{\max }$ dan $\mathrm{e}_{\min }$ pasir vulkanik Gunung Kelud hampir mendekati korelasi yang diusulkan oleh Cubrinovski dan Ishihara (2002). Namun demikian jumlah sampel yang sangat terbatas dari sampel pasir vulkanik Gunung Kelud masih memerlukan penelitian lebih lanjut untuk dapat menghasilkan korelasi antara $\mathrm{e}_{\max }$ dan $\mathrm{e}_{\min }$ yang lebih akurat.

\subsection{Pengujian Kapasitas Absorpsi}

Hasil pengujian kapasitas absorpsi untuk pasir vulkanik A sebesar 7,759\% dan pasir vulkanik B sebesar 6,383\%. Berikut merupakan gambar hasil pengujian kapasitas absorpsi ketika mencapai kondisi SSD (Saturated Surface Dry).

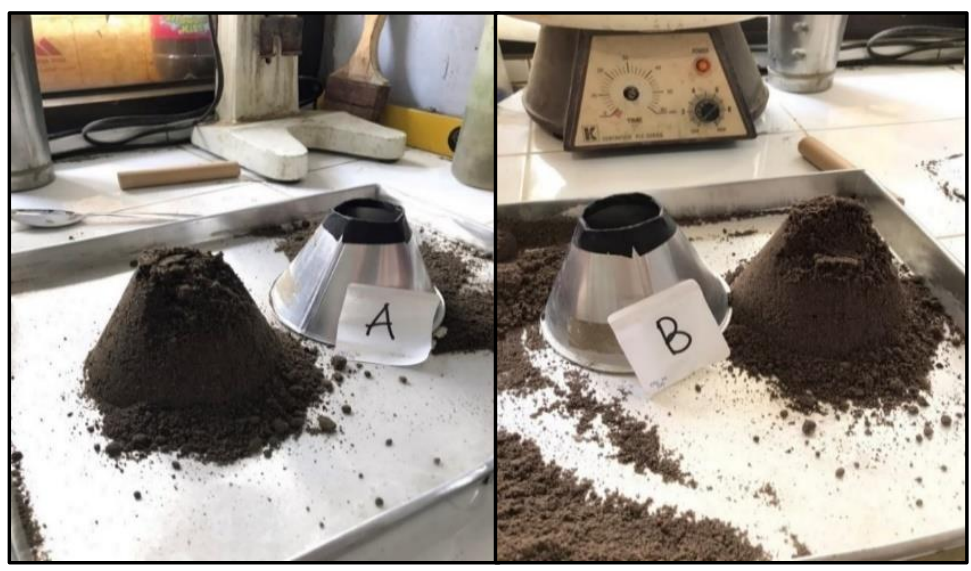

Gambar 4: Kondisi SSD Pasir Vulkanik

\subsection{Pengujian SEM (Scanning Electron Microscopes)}

Hasil dari pengujian SEM terdapat rongga-rongga udara yang tersebar di seluruh permukaan butiran sampel yang berukuran besar dan dipenuhi oleh partikel volcanic ash yang berukuran sangat halus. Berikut merupakan hasil SEM pada pasir vulkanik A. 


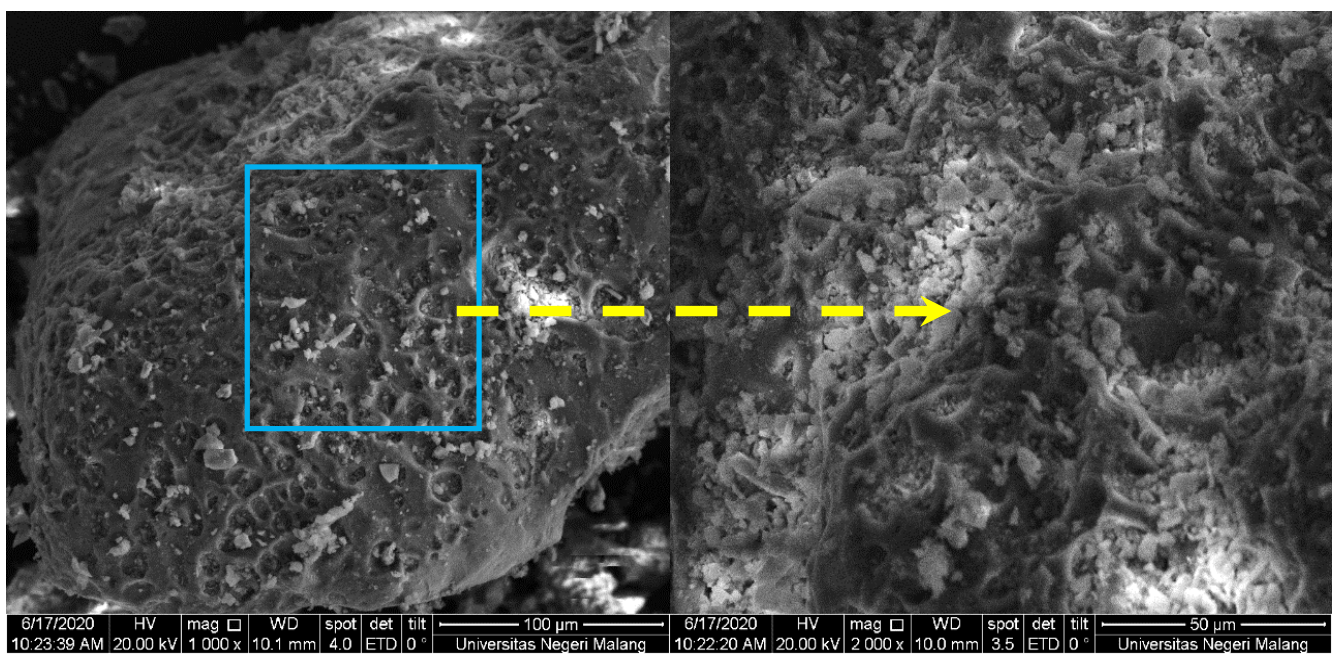

Gambar 5: Hasil Pengujian SEM

\subsection{Sphericity dan Roundness}

Dari hasil pengujian sphericity dan roundness didapat bahwa berdasarkan grafik Krumbein dan Zingg pada sampel di lokasi studi rata-rata termasuk ke dalam high sphericity dengan rentang kategori butiran angular hingga sub-angular serta memiliki bentuk butiran oblate. Karena didominasi oleh partikel dengan bentuk bersudut, maka gaya friksi antar butiran menjadi lebih besar dan meningkatkan gaya saling mengunci (interlocking) antar butiran. Berikut merupakan rekapitulasi hasil pengujian.

Tabel 4: Rekapitulasi Nilai Sphericity dan Roundness

\begin{tabular}{|c|c|c|c|}
\hline Sampel & Sphericity & Roundness & Keterangan \\
\hline \multicolumn{4}{|l|}{ A } \\
\hline 1 & 0,4 & 0,4 & Low Sphericity - Sub Angular \\
\hline 2 & 0,5 & 0,4 & High Sphericity - Sub Angular \\
\hline 3 & 0,4 & 0,4 & Low Sphericity - Sub Angular \\
\hline \multicolumn{4}{|l|}{$\mathrm{B}$} \\
\hline 1 & 0,5 & 0,4 & High Sphericity - Sub Angular \\
\hline 2 & 0,5 & 0,4 & High Sphericity - Sub Angular \\
\hline 3 & 0,5 & 0,3 & High Sphericity - Angular \\
\hline
\end{tabular}

\subsection{Klasifikasi Tanah}

Pada sistem klasifikasi tanah dibagi menjadi 3 (tiga) yaitu klasifikasi tanah menurut AASTHO (American Association Of State Highway and Transporting Official), klasifikasi tanah USCS (Unified Soil Clasification System), dan klasifikasi tanah JGS (The Japanese Geotechnical Society).

Tabel 5: Klasifikasi Tanah menurut AASTHO

\begin{tabular}{|c|c|c|}
\hline Sampel Tanah & Simbol & Jenis Tanah \\
\hline Vulkanik A & A-1b & $\begin{array}{l}\text { Tanah yang terdiri dari kerikil dan pasir kasar dengan sedikit } \\
\text { atau tanpa butir halus, dengan atau tanpa sifat plastis }\end{array}$ \\
\hline Vulkanik B & $A-1 b$ & $\begin{array}{l}\text { Tanah yang terdiri dari kerikil dan pasir kasar dengan sedikit } \\
\text { atau tanpa butir halus, dengan atau tanpa sifat plastis }\end{array}$ \\
\hline Vulkanik C & A-1b & $\begin{array}{l}\text { Tanah yang terdiri dari kerikil dan pasir kasar dengan sedikit } \\
\text { atau tanpa butir halus, dengan atau tanpa sifat plastis }\end{array}$ \\
\hline
\end{tabular}


Tabel 6: Klasifikasi Tanah menurut USCS

\begin{tabular}{cll}
\hline Sampel Tanah & \multicolumn{1}{c}{ Simbol } & \multicolumn{1}{c}{ Jenis Tanah } \\
\hline Vulkanik A & $\begin{array}{l}\text { SW (Sand Well- } \\
\text { graded })\end{array}$ & $\begin{array}{l}\text { Pasir bergradasi-baik, pasir } \\
\text { berkerikil, sedikit atau sama sekali } \\
\text { tidak mengandung butiran halus }\end{array}$ \\
Vulkanik B & $\begin{array}{l}\text { SP (Sand Poorly- } \\
\text { graded })\end{array}$ & $\begin{array}{l}\text { Pasir bergradasi-buruk, pasir } \\
\text { berkerikil, sedikit atau sama sekali } \\
\text { tidak mengandung butiran halus }\end{array}$ \\
Vulkanik C & $\begin{array}{l}\text { SW (Sand Well- } \\
\text { graded })\end{array}$ & $\begin{array}{l}\text { Pasir bergradasi-baik, pasir } \\
\text { berkerikil, sedikit atau sama sekali } \\
\text { tidak mengandung butiran halus }\end{array}$ \\
\hline
\end{tabular}

Tabel 7: Klasifikasi Tanah menurut JGS

\begin{tabular}{cccc}
\hline Sampel Tanah & $\begin{array}{c}\text { Lolos } \\
\text { Ayakan } \\
\text { no.200 }(\%)\end{array}$ & Simbol & Jenis Tanah \\
\hline Vulkanik A & 5,6 & S-V & Sand - Volcanic Soil \\
Vulkanik B & 2,81 & $\mathrm{~V}$ & Volcanic Soil \\
Vulkanik C & 4,86 & $\mathrm{~V}$ & Volcanic Soil \\
\hline
\end{tabular}

3.8 Pengujian X-RD (X-Ray Difraction)

Tabel 8: Presentase Kandungan Mineral

\begin{tabular}{cccc}
\hline Sampel & Anorthite (\%) & Cristobalite (\%) & Enstatite (\%) \\
\hline Vulkanik A & 76 & - & 24 \\
Vulkanik B & 80,2 & 2 & 17,8 \\
Vulkanik C & 77 & 2 & 21 \\
\hline
\end{tabular}

Berdasarkan hasil pengujian X-RD apabila dihubungkan dengan reaksi Bowen diketahui bahwa anorthite dan enstatite merupakan senyawa yang terkandung dalam material masih muda dan belum mengalami pelapukan secara sempurna. Akan tetapi, untuk cristobalite merupakan senyawa yang terkandung dalam material yang telah mengalami kristalisasi akhir atau pelapukan sempurna.

3.9 Pengujian SEM-EDX (Scanning Electron Microscopes - Energy Dispersive X-Ray)

Tabel 9: Hasil Kandungan Mineralogi Perbesaran 1000 Kali

\begin{tabular}{cccc}
\hline Sampel & Element & Wt\% & At\% \\
\hline & OK & 44,83 & 62,04 \\
& AlK & 10,81 & 8,87 \\
& SiK & 27,55 & 21,72 \\
& KK & 1,18 & 0,67 \\
& CaK & 3,27 & 1,81 \\
& FeK & 12,35 & 4,09 \\
\hline B & OK & 45,00 & 60,44 \\
\hline
\end{tabular}




\begin{tabular}{cccc}
\hline Sampel & Element & Wt\% & At\% \\
\hline \multirow{6}{*}{} & $\mathrm{NaK}$ & 4,57 & 4,27 \\
& $\mathrm{AlK}$ & 10,29 & 8,19 \\
& $\mathrm{SiK}$ & 28,78 & 22,02 \\
& $\mathrm{CaK}$ & 4,68 & 2,51 \\
& $\mathrm{FeK}$ & 6,68 & 2,57 \\
\hline \multirow{4}{*}{$\mathrm{OK}$} & 46,14 & 61,47 \\
& $\mathrm{NaK}$ & 3,48 & 3,23 \\
& $\mathrm{AlK}$ & 11,16 & 8,82 \\
& $\mathrm{SiK}$ & 27,78 & 21,09 \\
& $\mathrm{KK}$ & 1,85 & 1,01 \\
& $\mathrm{CaK}$ & 4,84 & 2,57 \\
& $\mathrm{FeK}$ & 4,74 & 1,81 \\
\hline
\end{tabular}

Berdasarkan hasil pengujian didapat bahwa pasir vulkanik A dan tanah vulkanik B mengandung presentase unsur $\mathrm{O}, \mathrm{Si}, \mathrm{Fe}$, dan $\mathrm{Al}$ yang tinggi dan merupakan jenis Almandine $\left(\mathrm{Fe}_{3} \mathrm{Al}_{2}\left(\mathrm{SiO}_{4}\right)_{3}\right)$ dari kelompok Gernet yaitu mineral Nesosilicates. Almadine merupaka besi yang mewakili kelompok penting pembentuk silikat dan termasuk penyusun utama kerak bumi. Sedangkan untuk pasir vulkanik $\mathrm{C}$ presentase unsur tinggi yaitu $\mathrm{O}, \mathrm{Si}$ dan $\mathrm{Al}$ dan merupakan jenis Kyanite $\left(\mathrm{Al}_{2} \mathrm{SiO}_{5}\right)$ yaitu mineral aluminosilikat atau Nesosilicates. Kyanite ini biasanya ditemukan di batuan metamorf yang kaya akan aluminium atau batuan sedimen.

\subsection{Pengujian X-RF (X-Ray Fluorescence)}

Hasil dri pengujian X-RF dibandingkan dengan beberapa penelitian sebelumnya tentang komposisi senyawa yang terkandung dalam material sampel pasir vulkanik, dapat dilihat pada Tabel 10 berikut.

Tabel 10: Komposisi Senyawa Hasil Uji X-RF

\begin{tabular}{ccccccc}
\hline No & Senyawa & $\begin{array}{c}\text { Sampel } \\
\mathrm{A}^{\mathrm{a}}\end{array}$ & $\begin{array}{c}\text { Sampel } \\
\mathrm{B}^{\mathrm{a}}\end{array}$ & $\begin{array}{c}\text { \% dalam sampel } \\
\text { Shirasu }^{\mathrm{b}}\end{array}$ & $\begin{array}{c}\text { Pampean loess }^{\mathrm{c}}{ }^{\mathrm{N}} \\
\text { (Argentina) }\end{array}$ & $\begin{array}{c}\text { Cemented sand }^{\mathrm{d}} \\
\text { (Kuwait) }\end{array}$ \\
\hline 1 & $\mathrm{SiO}_{2}$ & 45,90 & 55,30 & 76,60 & 67,82 & 65,20 \\
2 & $\mathrm{Al}_{2} \mathrm{O}_{3}$ & 15,00 & 12,00 & 12,20 & 12,30 & 9,94 \\
3 & $\mathrm{~K}_{2} \mathrm{O}$ & 1,16 & 2,08 & 3,54 & & 1,92 \\
4 & $\mathrm{CaO}$ & 15,70 & 12,50 & 1,08 & & 1,75 \\
5 & $\mathrm{Fe}_{2} \mathrm{O}_{3}$ & 19,40 & 15,50 & 1,48 & Tidak ada & 5,88 \\
6 & $\mathrm{MnO}_{7}$ & 0,43 & 0,38 & - & data & 0,05 \\
7 & $\mathrm{TiO}_{2}$ & 1,37 & 1,11 & - & & 0,77 \\
9 & $\mathrm{BaO}$ & 0,10 & 0,20 & - & & - \\
9 & $\mathrm{Lainnya}$ & 0,94 & 0,93 & 5,10 & 19,88 & 14,49 \\
\hline
\end{tabular}

Komposisi senyawa hasil uji XRF dari sampel pasir vulkanik A dan B yang dibandingkan dengan beberapa pasir vulkanik yang berasal dari berbagai sumber terdapat adanya kesamaan yaitu pasir vulkanik memiliki kandungan senyawa $\mathrm{SiO}_{2}$ yang dominan. Suatu material dapat bersifat pozzolan bila memiliki kandungan silika dan alumina yang tinggi [9]. Material yang memiliki kandungan total $\mathrm{SiO}_{2}$, $\mathrm{Al}_{2} \mathrm{O}_{3}$ dan $\mathrm{Fe}_{2} \mathrm{O}_{3}$ yang lebih tinggi dari 50\% dan kandungan $\mathrm{CaO}$ kurang dari $10 \%$ dapat dikategorikan 
sebagai material yang bersifat pozolanik dan mudah tersementasi (cementitious properties) [10]. Sesuai standar ini maka sampel pasir vulkanik A dan B termasuk bersifat pozzolanik.

\subsection{Pengujian Kekuatan Geser Langsung (Direct Shear)}

Pada pengujian kuat geser tanah material sampel dilakukan dengan pemodelan Dr 50\% dan Dr $70 \%$ didapat hasil sebagai berikut:

Tabel 11: Hasil Pengujian Kuat Geser

\begin{tabular}{cccc}
\hline Sampel & Persamaan Grafiik Uji Gese Langsung & Kohesi & Sudut Geser Tanah \\
\hline A; Dr 50\% & $\mathrm{y}=0,8315 \mathrm{x}+0,0928$ & 0,093 & $39,74^{\circ}$ \\
A; Dr 70\% & $\mathrm{y}=1,1033 \mathrm{x}+0,0103$ & 0,010 & $47,81^{\circ}$ \\
B; Dr 50\% & $\mathrm{y}=1,0714 \mathrm{x}+0,0227$ & 0,023 & $46,97^{\circ}$ \\
B; Dr 70\% & $\mathrm{y}=0,9274 \mathrm{x}+0,0475$ & 0,048 & $42,84^{\circ}$ \\
\hline
\end{tabular}

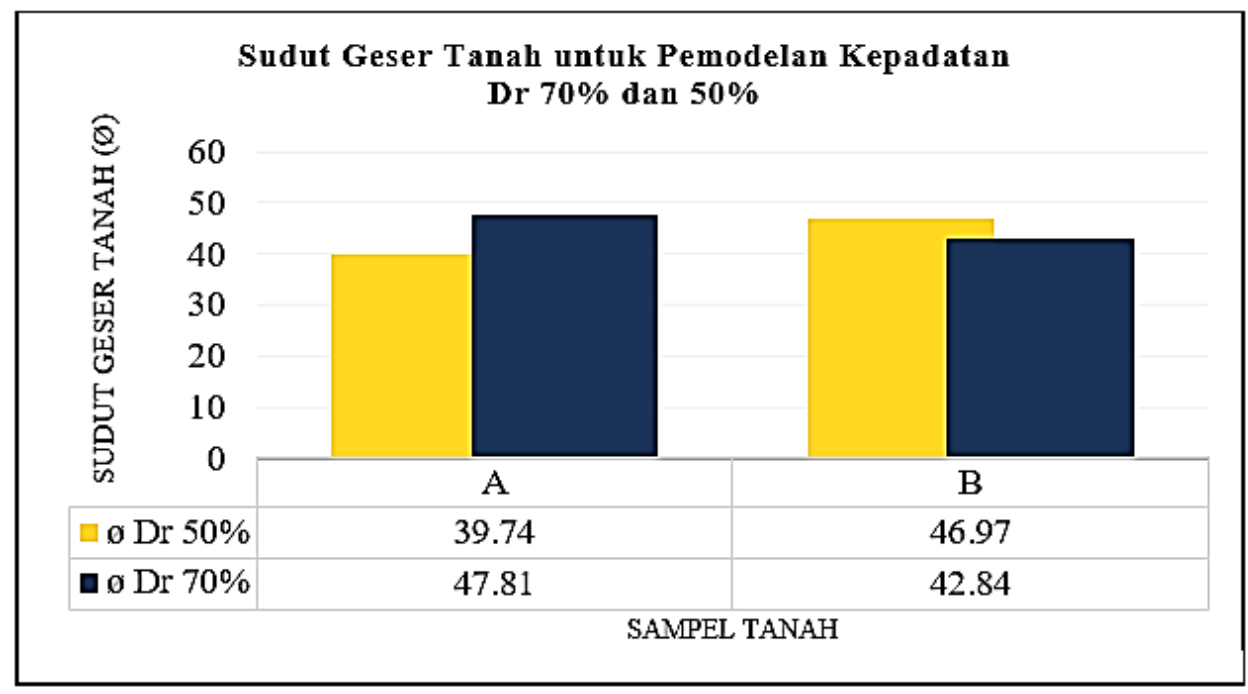

\section{Gambar 6: Grafik Nilai Sudut Geser}

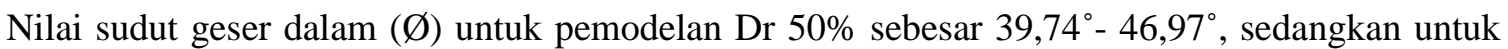
pemodelan Dr $70 \%$ sebesar $42,84^{\circ}-47,81^{\circ}$ dan dapat dikelompokkan kedalam tipe tanah jenis krikil bercampur pasir yang memiliki nilai rata-rata sudut geser dalam $(\varnothing)$ sebesar $34-48^{\circ}$.

\subsection{Pengujian Sudut Tenang (Angle of Repose)}

Pengujian sudut tenang (angle of repose) digunakan untuk mengetahui sudut tenang dari 2 (dua) sampel di lokasi studi. Dalam pengujian ini menggunakan metode pengamatan langsung dengan perhitungan lebar dan tinggi sehingga akan didapatkan nilai sudut tenang berdasarkan hasil perhitungan. Untuk sampel tanah vulkanik yang akan diuji, dilakukan 3 (tiga) kali percobaan agar lebih akurat. 
Tabel 12: Rekapitulasi Hasil Pengujian Angle of Repose pada Sampel

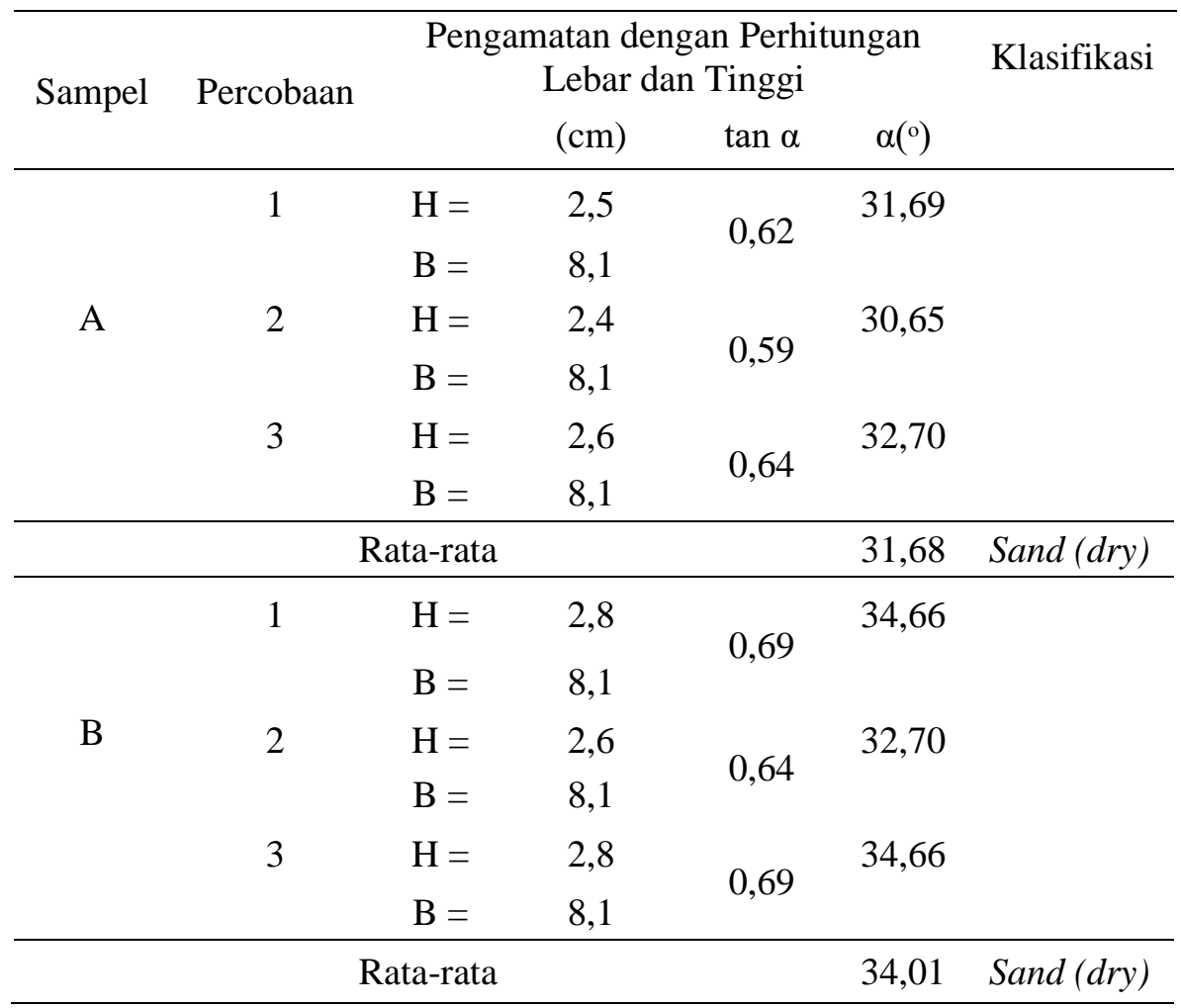

Pada pengujian ini didapat hasil dari rata-rata perhitungan lebar dan tinggi yaitu sampel pasir vulkanik $\mathrm{A}=31,68^{\circ}$, pasir vulkanik $\mathrm{B}=34,01^{\circ}$ dan diklasifikasikan sebagai sand (dry). Tingginya nilai sudut tenang karena bentuk butiran yang bersudut tajam dan kekasaran permukaan sehingga memiliki ketahanan yang tinggi dalam menahan kelongsoran.

\section{Kesimpulan}

Pada pengujian karakteristik fisik didapat bahwa sampel material bergradasi baik dan buruk dengan memiliki nilai Gs yang cukup tinggi dikarenakan berdasarkan hasil scanning electron microscopes terdapat partikel sangat halus yang mengisi pori/rongga yang berukuran lebih besar pada permukaan butiran pasir vulkanik. Berdasarkan hasil klasifikasi tanah menurut AASHTO bahwa pasir vulkanik bergradasi baik berupa krikil dengan sedikit atau tanpa butir halus, sedangkan menurut USCS bahwa pasir vulkanik A berupa sand well-graded dan pasir vulkanik B berupa poorly well-graded, dan menurut JGS bahwa pasir vulkanik A yaitu sand-volcanic dan pasir vulkanik B yaitu volcanic soil.

Untuk pengujian karakteristik mineralogi didapat bahwa kandungan mineral yang terdapat pada sampel seperti $\mathrm{SiO} 2, \mathrm{Fe} 2 \mathrm{O} 3, \mathrm{CaO}$, dan $\mathrm{A} 12 \mathrm{O} 3$ yang cukup tinggi sehingga membuktikan bahwa material sampel tersebut bersifat pozolnik atau mudah tersementasi. Sedangkan untuk pengujian karakteristik mekanik didapat nilai sudut geser dalam $(\varnothing)$ untuk pemodelan Dr 50\% sebesar 39,74 $46,97^{\circ}$, sedangkan untuk pemodelan Dr $70 \%$ sebesar $42,84^{\circ}-47,81^{\circ}$ dan dapat dikelompokkan kedalam tipe tanah jenis krikil bercampur pasir. Sampel tanah tersebut memiliki nilai sudut geser dalam yang cukup tinggi, hal tersebut dipengaruhi oleh bentuk dari sampel tanah yang bersudut sehingga material tersebut dapat mengikat antar partikel satu sama lain sehingga menjadi lebih kuat dan pengukuran sudut tenang memiliki nilai $31,68^{\circ}$ dan $34,01^{\circ}$. 


\section{Daftar Pustaka}

[1] A. Zaennudin, "Prakiraan bahaya erupsi Gunung Kelud. Bulletin Vulkanologi Dan Bencana Geologi", 4(2), 1-17, 2009.

[2] T.D. O'Rourke \& E. Crespo, "Geotechnical Properties of Cemented Volcanic Soil.” Journal of Geotechnical Engineering, 114(10), 1126-1147, 1988.

[3] B. D. Collins \& N. Sitar, "Geotechnical Properties of Cemented Sands in Steep Slopes.' Journal of Geotechnical and Geoenvironmental Engineering, ASCE, 2009.

[4] N.F. Ismael, "Properties and behavior of cemented sand deposits in Kuwait", Soils and Foundations, vol. 39, no. 4, 47-57, The Japanese Geotechnical Society, 1999.

[5] N. Sitar, G. W. Clough, R.C. Bachus, "Behavior of Weakly Cemented Soil Slopes Under Static and Seismic Loading Conditions." United States Geological Survey Department of the Interior, 1980.

[6] D. O. Latif, A. Rifa'i, \& K. B. Suryolelono, "Chemical Characteristics of Volcanic Ash in Indonesia for Soil Stabilization: Morphology and Mineral Content" International Journal of GEOMATE, Vol. 11, Issue 26, Oct., 2016, pp. 2606 - 2016 2610. Geotec. Const. Mat, 2016.

[7] F. Aristantha, "Identifikasi Karakteristik Fisik dan Mineralogi Material Piroklastik Hasil Erupsi Gunung Kelud di Sungai Kali Sambong Desa Pandansari Kecamatan Ngantang Kabupaten Malang sebagai Alternatif Material Timbunan.” Malang: Universitas Brawijaya, 2017.

[8] G.I. Sudewo, A. P. Hendrawan \& D. Sisinggih, "Evaluasi Karakteristik Kuat Geser Material Tebing Sungai Di Lokasi Kelongsoran Penambangan Pasir Kali Putih, Kecamatan Garum Kabupaten Blitar.” Skripsi. Mahasiswa Jurusan Teknik Pengairan, Universitas Brawijaya, 2019.

[9] E Quintana \& E. Redolfi, "Evaluation of pozzolanic activity of Pampean Loess." XV Conference Int. of Soil Mech. and Geotech. Engn. Estambul.Vol 1.: 243 - 246, 2001.

[10] ASTM C618-08a. "Standard Specification for Coal Fly Ash and Raw or Calcined Natural Pozzolan for Use in Concrete.” ASTM International, West Conshohocken, 2008. 